American Journal of Environmental Sciences 7 (6): 492-498, 2011

ISSN 1553-345X

(C) 2011 Science Publications

\title{
A Rule-Based Expert System for Construction and Demolition Waste Management
}

\author{
${ }^{1}$ Leila Ooshaksaraie, ${ }^{2}$ Alireza Mardookhpour \\ ${ }^{1}$ Department of Environment, Faculty of Natural Resources, \\ Lahijan Branch, Islamic Azad University, Lahijan, Iran \\ ${ }^{2}$ Department of Civil and Water Engineering, \\ Lahijan Branch, Islamic Azad University, Lahijan, Iran
}

\begin{abstract}
Problem statement: The construction industry generates lots of construction waste which caused significant impacts on the environment and aroused growing public concern in the local community. Construction waste is becoming a serious environmental problem in many large cities in the world. Approach: In recent years, expert systems have been used extensively in different applications areas including environmental studies. In this study, expert system software -CDWMdeveloped by using Microsoft Visual Basic was introduced. CDWM to be used for construction waste management plan was designed based on the legal process. Results: According to the construction waste management regulation enacted, construction activities require mandatory construction waste management plan before staring activities. CDWM primarily aims to provide educational and support system for construction engineers and decision-makers during construction activities. It displays construction waste management plan in report form and the best location of construction waste storage area in GIS format. Conclusion: When the use of CDWM in construction waste management plan becomes widespread, it is highly possible that it will be benefited in terms of having more accurate and objective decisions on construction projects which are mainly focused on reducing the construction waste.
\end{abstract}

Key words: Artificial intelligent system, geographical information system, regulatory requirements, pollution mitigation measures, Best Management Practices (BMPs)

\section{INTRODUCTION}

Expansion of urban areas is the main causes of land use change (Solaimani et al., 2009). In urban development, construction sector plays major role. It provides the direct means to the development and is, at the same time, a major polluter of the environment (Baris and Erik, 2000). A very high level of waste is assumed to exist in construction industry (Carlos et al., 2002). This kind of waste typically accounts for between 15 and $30 \%$ of urban waste (Kibert, 1994; Bossink and Brouwers, 1996; Carlos et al., 2002). Construction waste is becoming a serious environmental problem in many large cities in the world. The construction industry generates lots of construction waste which caused significant impacts on the environment and aroused growing public concern in the local community. Thus, the minimization of construction wastes has become a pressing issue (Begum et al., 2006).

Kilbert (1994) pointed out that construction activity generates approximately $20-30 \%$ of all wastes deposited in Australian landfills. Poon (1997) noted that construction wastes represent a large share among all types of solid wastes. His study shows that construction debris resulting from construction and demolition works constitute a particularly large proportion of all the solid wastes. Cotton et al. (1999) reported that uncollected construction solid wastes have become a major health hazard (Shen et al. 2004). All these studies demonstrate that the construction industry is a large contributor to waste generation. Therefore, waste management during construction activities has been promoted for the aim of protecting the environment in line with the recognition that the wastes from construction works contributes significantly to the polluted environment (Shen et al. 2004). There are three significant steps involved in the waste management plan during construction activities:

- Information about construction stage

- Consideration of all various waste to be generated from the site

- Evaluation of the collected data in an accurate way

Corresponding author: Leila Ooshaksaraie, Department of Environment, Faculty of Natural Resources, Lahijan Branch, Islamic Azad University, Lahijan, Iran 
This evaluation is completed before decisions related to the controlling construction wastes are taken and it is a challenging process requiring intense knowledge, experience and data. Waste management plan is continuously monitored to meet related regulations. Assessing and preparing the waste management plan are the most important and timeconsuming task that relates to various information, data, domain law, expert knowledge and experience in terms of construction activities, environmental management and protection. Therefore, there needs to be a support system for collecting, analyzing and reporting information (Say et al., 2008; Muthusamy and Ramalingam, 2003). Expert system is a computer based system utilizes data and model to support decision maker for solving unstructured problems (Hartati and Sitanggang, 2010). It is promising technology that manages data and information and provides the required expertise (Say et al., 2008). It thus seem well suited to many of tasks associated with waste management plan.

In order to improve controlling construction wastes, existing research work has developed a rule-based expert system, CDWM "Construction and Demolition Waste Management". It aims to inform the project owner, the consultants and decision-makers at the waste management plan preparing in the most accurate, the newest and the fastest way. CDWM has been developed based on Visual Basic software 6 which satisfies certain requirements. The motivations for the project were the following:

- There are many development projects over the world; therefore the identification of the waste management plan is of major practical interest for them

- No similar work on construction activities has been undertaken by the use of expert systems

Developed guidelines related to the construction site Best Management Practices; do not fulfill certain requirements of the waste management plan. Some guidance was provided to develop ways in which to avoid or minimize waste, no specific guidelines were established in work process optimization, material planning and on-site training.

\section{MATERIALS AND METHODS}

Construction and demolition waste: Construction waste is in the form of building debris, earth, timber, steel, concrete and mixed site clearance materials, arising from various construction activities including land excavation or formation, demolition activities, site clearance, roadwork, building construction and building renovation (Shen et al. 2004; Tam et al. 2005). Construction activities also generate chemical and other special wastes, which are normally regulated strictly for special treatment as they can easily become risks to health or cause pollution to the environment (Shen et al. 2004). Special wastes are described including asbestos, livestock waste, sludge rising from excavation, waterworks treatment and sewage treatment sludge (Shen et al. 2004). Table 1 lists the sources of pollutants at construction waste including sediment, the primary pollutant and other pollutants such as $\mathrm{BOD}, \mathrm{COD}, \mathrm{DO}, \mathrm{pH}, \mathrm{NH}_{3}-$ $\mathrm{N}$, Oil and Grease that are considered in this study.

Poon et al. (2001) illustrated whilst some of construction wastes are reusable and recyclable, they are usually dumped at landfills. Site formation works and the remaining waste is often contaminated and mixed, not suitable for recycling or reuse but disposed of at landfills (Tam et al. 2005). The separation of the special and chemical wastes from other types of construction wastes helps the adoption of specific methods for dealing with different types of wastes effectively (Shen et al. 2004). Spivey (1974) documented one of the earliest efforts to categorize construction wastes. He classified the most common components of construction waste as follows: (1) demolition materials (i.e., concrete, plaster, brick and used lumber); (2) wood (including trees and scrap lumber); (3) packaging materials (i.e., paper, plastic, cardboard and metal retaining bands); (4) waste concrete and asphalt; (5) garbage and sanitary waste; (6) glass, rubber and plastic; (7) scrap-metal products; and (8) pesticides and pesticide containers (Gavilan and Bernold, 1994.)

Table 1: Sources of pollutants at construction waste

\begin{tabular}{|c|c|c|c|c|c|c|}
\hline \multirow[b]{3}{*}{ Areas of consideration } & \multicolumn{6}{|c|}{ Construction site pollutants } \\
\hline & \multirow{2}{*}{$\begin{array}{l}\text { Primary } \\
\text { Pollutant } \\
\text { Sediment }\end{array}$} & \multicolumn{5}{|c|}{ Other pollutant } \\
\hline & & Nutrients & $\mathrm{pH}$ & $\mathrm{BOD}, \mathrm{COD}, \mathrm{DO}$ & Oil and grease & Trash, debris, solids \\
\hline Concrete washout and waste & & & $\sqrt{ }$ & & & $\sqrt{1}$ \\
\hline Demolition and debris disposal & $\sqrt{ }$ & & & & & $\sqrt{ }$ \\
\hline Solid waste (trash and debris) & & & & $\sqrt{ }$ & & $\sqrt{ }$ \\
\hline Hazardous waste & & & $\sqrt{ }$ & & $\sqrt{ }$ & \\
\hline Contaminated spills & & $\sqrt{ }$ & $\sqrt{ }$ & & $\sqrt{ }$ & \\
\hline Sanitary/septic waste & & $\sqrt{ }$ & $\sqrt{ }$ & $\sqrt{ }$ & $\sqrt{ }$ & \\
\hline
\end{tabular}

Source: EPA 2007 
Petts (1995) suggested building an agreement among the public regarding the impact of waste on the environment and promoted proactive community involvement in implementing waste management. In recent years, waste reuse and recycle have been widely promoted for reducing the volume of wastes, but the effectiveness of their application is limited largely because the conditions for applying these approaches were not provided (Peng et al., 1997).

These conditions include selecting proper site location and equipment for waste sorting, experience of reusing and recycling waste, providing trained supervisors and employees and knowledge of environmental regulations. Faniran and Caban (1998) classified waste management methodologies in a hierarchy in descending order: reducing waste; reusing waste; recycling waste and disposing waste where the first three options are not possible. Recently, using environmentally friendly construction methods has been encouraged. Shen and Tam (2002) applying waste management methods as part of project management functions. It is suggested to design specific training programs for different groups of staff. In fact, their study indicates that waste management has been receiving less attention from senior management within organizations. The reason illustrated is that the cost for implementing waste management is given more concern than the possible benefits that the organization can gain from the implementation (Shen and Tam, 2002; Shen et al., 2004). McDonald and Smithers (1998) conducted a survey suggesting that a proper waste management plan can contribute significantly to eliminate waste source and can result in up to $50 \%$ cost savings for waste handling charges, $15 \%$ volume reduction of waste generation prior to recycling on site and $43 \%$ waste reduction for landfill. However, there is lack of methodology in providing guidelines on how to produce a proper waste management plan (Shen $e t$ al. 2004).

It is a fact that construction waste cause environmental problems. Mainly for this reason, the reliability and quality of waste management plans have great importance in the implementing construction projects in terms of having the least negative impact on environment. The reliability and quality of waste management plans can be increased by having this kind of software which covers the information on the legal waste minimization process. To mitigate these problems, an expert system, "CDWM", was designed for the objective construction waste management through:

- Diagnosis of the waste sources from the site

- Identification of selected waste with probable adverse impacts

- Planning action to cope with indicated waste from the construction site

- Providing advice on ways to reduce waste at construction site

"CDWM" attempts to provide waste management control measures based on the experts knowledge.

CDWM framework: Expert system simulates the learning, reasoning, communication and action processes of a human expert in a given area of science. In this way, it gives a consultant that can substitute the human expert systems with reasonable guaranties of success. These characteristics allow expert system to store data and knowledge, learn from existing data and experience, draw logical conclusions, make decisions, communicate with other human experts or expert systems, explain why decision have been made and take actions as a consequence of all the above (Deprizon et $a l ., 2009)$. The expert system has been successfully applied in various domains, such as agricultural management, water quality management, environmental protection, waste management, wastewater treatment and urban design (Liao, 2005). Therefore, it seem well suited to construction waste management study. For detect the problem and guide the user, a system needs to develop through the diagnostic and advisory process that knowledge is represented by rules (Negnevitsky, 2005). The simplest way for executing the system is to explicit knowledge directly from experts, rule by rule (Karnib et al., 2002). This system usually requires explanation facilities to justify their solutions to the user. Such facilities are an essential component of expert system (Negnevitsky, 2005). Therefore, a rulebased expert system and forward chaining inference mechanism are used to develop the CDWM.

In development phase of the CDWM, few meeting were organized to consult with five experts whom three experts were from university, while the others, from consultant. Experts diagnose critical factors including associated regulations and expert experience that derive the control measures for waste management on construction sites. The law and experts' evaluation processes regarding waste management are considered to construct the expert decision model and subsequently develop the inference engine. Certainty factor is used to measure the expert belief or disbelief the system rules. 


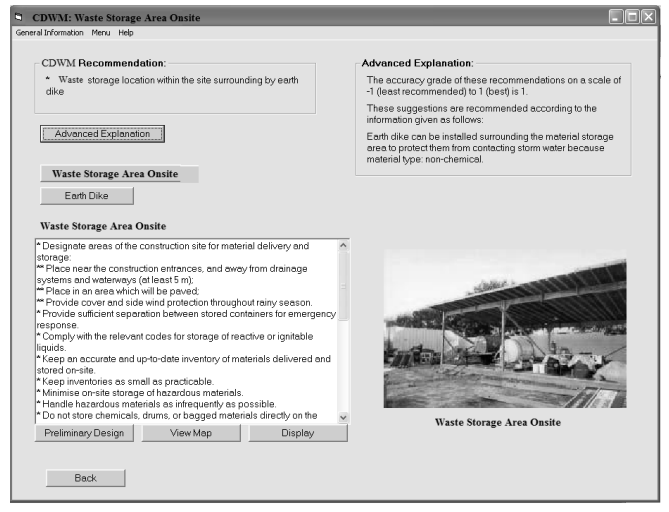

Fig. 1: Sample screen of CDWM recommendation

Table 2: CDWM characteristics

\begin{tabular}{ll}
\hline Items & Characteristics \\
\hline $\begin{array}{l}\text { Domain } \\
\text { Knowledge resources }\end{array}$ & $\begin{array}{l}\text { Construction waste management } \\
\text { Textbooks, guidelines, research } \\
\text { publications, expertise } \\
\text { Knowledge acquisition technique } \\
\text { Interview with experts, } \\
\text { certainty factor }\end{array}$ \\
$\begin{array}{l}\text { Knowledge representation } \\
\text { technique }\end{array}$ & $\begin{array}{l}\text { Rules } \\
\text { Inference engine }\end{array}$ \\
Explanation facility & $\begin{array}{l}\text { Forward chaining } \\
\text { Relation between regulations and } \\
\text { expertise analysis }\end{array}$ \\
Development method & $\begin{array}{l}\text { Prototype } \\
\text { Visual basic } \\
\text { Development tool }\end{array}$ \\
User interface & Visual basic \\
Objectives & $\begin{array}{l}\text { To help in preventing waste } \\
\text { management at construction site }\end{array}$ \\
\hline
\end{tabular}

CDWM is developed by using Microsoft Visual Basic 6 (VB). It enables users to enter information requested and the system then assesses data for the inference mechanism to derive the system results and recommendation. Geographic Information System (GIS) tool is one of the most powerful devices for storing, analyzing and modeling of geographic data (Khojastehfar et al., 2009). For this reason, the interface of CDWM utilizes GIS functions as a supportive component to display spatial maps for visualization of best location of waste storage area. It is more effective and efficient that is able to fulfill the need for mapping and planning (Hasmadi et al., 2010). In addition CDWM provides explanation facility to explain how the system arrived at certain results and to justify the matched rules based on accuracy grade. A sample screen of displaying system recommendation is shown in Fig. 1. The characteristics of the CDWM are presented in Table 2 that states domain, knowledge resources, knowledge acquisition technique, knowledge representation technique, inference engine, explanation facility, development method, development tool, user interface and objectives of the CDWM.

The developed CDWM is tested and evaluated in a variety of scenarios and the test outputs generated at each stage are checked, validated and revised. Modifications, improvements and testing of system are continuous processes that take place in CDWM development.

\section{RESULTS}

CDWM is designed in such a way that a series of general and specific questions can be answered by a proposed conceptual structure of the relational database such as:

- How can waste type be identified at construction site?

- What is the probable source of generated waste from the site?

- What is the adverse impact of construction waste on environment?

- When is the suitable timing collection of waste with each stage of the construction or demolition project?

- Where is the best location for waste collection area within the site?

- How can waste generation be reduced at its source?

- What is the suitable technique for construction waste management; reduce, recycle, reuse or disposal?

- How can train employees and subcontractors in waste management techniques?

System enables to identify waste type from the given construction site that can be include demolition materials, packaging materials, wood, waste concrete and asphalt, garbage and sanitary waste, chemical waste, scrap material product, rubber, plastic and glass. Therefore, CDWM can check three hypotheses:

- Hypothesis 1: The solid waste is generated from the construction site

- Hypothesis 2: The hazardous waste is produced by construction activities

- Hypothesis 3: The contaminated soil is caused by construction and building site

- Hypothesis 4: The concrete waste is generated from the construction activity

- Hypothesis 5: The sanitary waste is produced by construction worker

The goal is to identify, within a construction site, the most probable construction activities as waste generation source and to give proposal on the implementation of BMPs in order to manage the construction waste.

\section{DISCUSSION}

The content of the program consists of construction waste management plan during construction activities. The working system of the program is given in Fig. 2. 
Am. J. Environ. Sci., 7 (6): 492-498, 2011

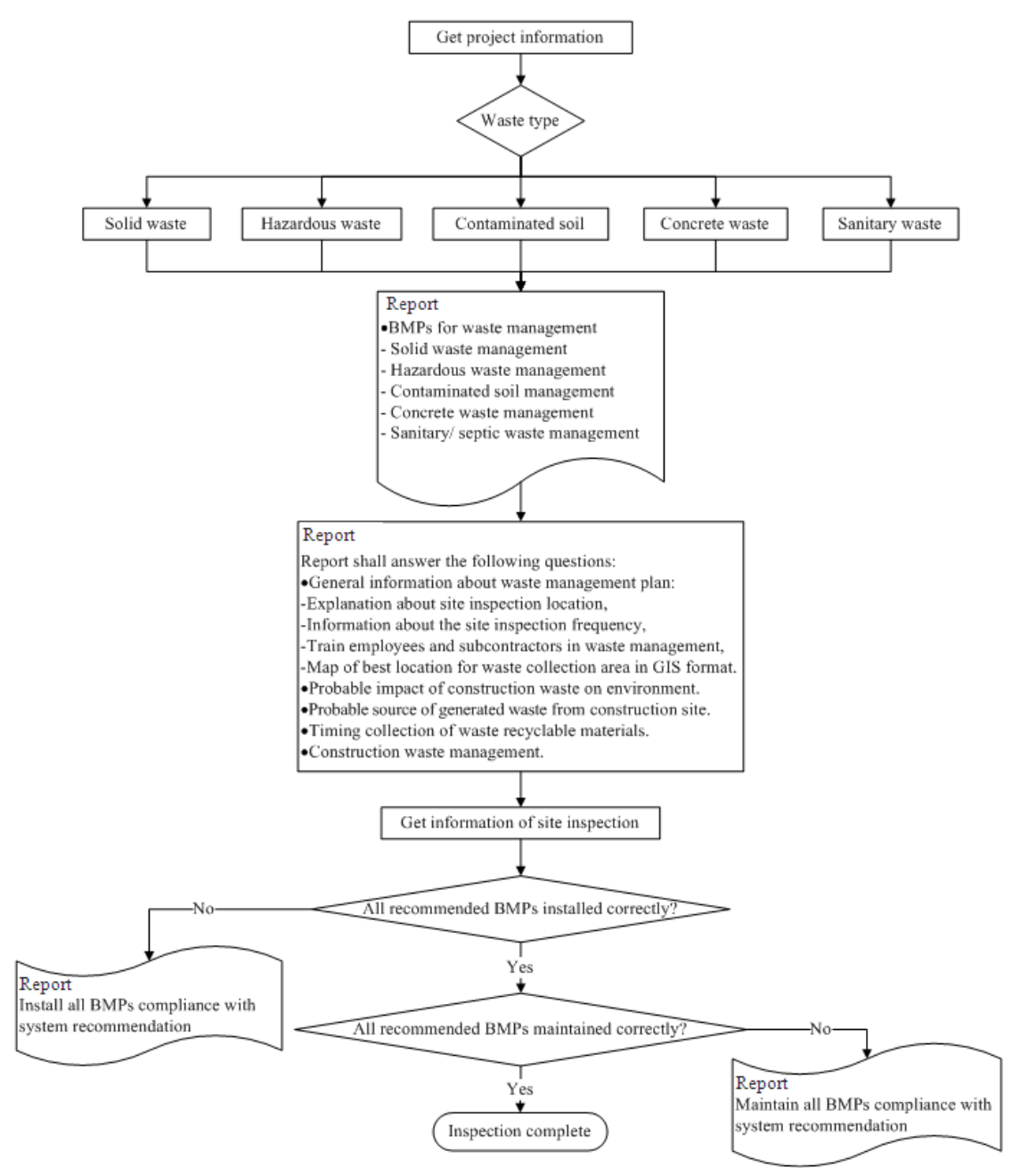

Fig. 2: General structure of CDWM

The database, including information about construction stage, probable source of generated waste, type of construction waste, impact of construction waste on environment, timing collection of waste, best location for waste collection area, construction waste management, train employees and subcontractors in waste management has been prepared.

The program primarily aims to inform the project owners and decision-makers on the following themes:

General information about waste management plan: The program presents the user various information related to the waste management plan on construction sites:

- Explanation about site inspection location,

- Information about the site inspection frequency,

- Train employees and subcontractors in waste management,
- Map of best location for waste collection area in GIS format

An example was made for a construction site by running the software. As a first step, after entering the information of the project's location, the construction site can be seen on screen. After the queries are completed, related result map is linked from the database and monitored on the screen to view the BMPs locations.

- Probable impact of construction waste on environment: The program presents adverse impacts of construction waste on environment

- Probable source of generated waste from construction site: probable source of generated waste that indicated to the construction site is informed to the user 
- Timing collection of waste: It suggests the user on timing collection of construction waste

- Construction waste management: Finally it recommends the user on construction waste management by referring to the BMPs on construction site

\section{CONCLUSION}

The construction industry generates lots of construction waste which caused significant impacts on the environment. Therefore, BMP is needed during construction activities. In line with this, it is very essential to use the most reliable and newest method for waste management plan to be used on construction sites. CDWM may be regarded as a tool to use in BMPs during construction activities. The most difficult phase of the study is to obtain expertise and information and transferring this knowledge and experience into the database. It will be possible to make use of the database when the data are completed as a result of the inventories about the probable source of generated waste, type of construction waste, impact of construction waste on environment, construction waste management plan. Then, the database will be used about construction waste management related to the every construction site. As a result, when the use of CDWM in construction waste management becomes widespread, it is highly possible that it will be benefited in terms of having more accurate and objective decisions on construction projects which are mainly focused on reducing the waste generation.

\section{ACKNOWLEDGEMENT}

This project was completed under Islamic Azad University-Lahijan Branch research grant. Financial support from the Islamic Azad University-Lahijan Branch is gratefully acknowledged.

\section{REFRENCES}

Baris, D.P. and J. Erik, 2000. Construction and environment-improving energy efficiency. J. Buil., 10: 3-21.

Bossink, B.A.G. and H.J.H. Brouwers, 1996. Construction waste: Quantification and source evaluation. J. Constr. Eng. Manage., 122: 55-60.

Begum, R.A., C. Siwar, J.J. Pereira and A.H. Jaafar, 2006. A benefit-cost analysis on the economic feasibility of construction waste minimisation: The case of Malaysia. J. Resources Conserv. Recycl., 48: 86-98. DOI:10.1016/j.resconrec.2006.01.004
Carlos, T.F., L. Soibelman, C.L.D. Cesare and E.L. Isatto, 2002. Material waste in building industry: main causes and prevention. J. Constr. Eng. Manage., 128: 316-325.

Cotton, A., M. Snel and M. Ali, 1999. The challenges ahead-solid waste management in the next millennium. Waterlines, 17: 2-5.

Deprizon, S., D. Amiruddin and R. Atiq, 2009. Development of knowledge-based expert system for flexible pavement design. J. Applied Sci., 9: 2372-2380.

EPA, 2007. Developing Your Stormwater Pollution Prevention Plan: A Guide for Construction Site. $1^{\text {st }}$ Edn., U.S. Environmental Protection Agency, Washington, pp: 46.

Faniran, O.O. and G. Caban, 1998. Minimizing waste on construction project sites. Eng., Constr., Archit. Manage., 5: 182-188. DOI: 10.1108/eb021073

Gavilan, R.M. and L.E. Bernold, 1994. Source evaluation of solid waste in building construction. J. Constr. Eng. Manag., 120: 536-536. DOI: 10.1061/(ASCE)0733-9364(1994)120:3(536)

Hartati, S. and I.S.M. Sitanggang, 2010. A fuzzy based decision support system for evaluating land suitability and selecting crops. J. Comput. Sci.., 6: 417-424. DOI: 10.3844 /jcssp.2010.417.424

Hasmadi, I.M., H.Z. Pakhriazad and F.S. Mohamad, 2010. Geographic information system-allocation model for forest path: a case study in ayer hitam forest reserve, Malaysia. Am. J. Applied Sci., 7: 376-380. DOI: 10.3844/ajassp.2010.376.380

Kibert, C.J., 1994. Sustainable Construction: Green Building Design and Delivery. 2nd Edn., John Wiley and Sons, Hoboken, ISBN: 0470114215, pp: 407.

Peng, C.L., D.E. Scorpio and C.J. Kibert, 1997. Strategies for successful construction and demolition waste recycling operations. J. Constr. Manage. Econ., 15: 49-58. DOI: 10.1080/014461997373105

Kilbert, C.J., 1994. Sustainable Construction. 1st Edn., University of Florida, Gainesville, pp: 888.

Karnib, A., J. Al-Hajjar and D. Boissier, 2002. An expert system to evaluate the sensitivity of urban areas to the functioning failure of storm drainage networks. J. Urban Water, 4: 43-51. DOI:10.1016/S1462-0758(01)00063-2.

Khojastehfar, E., A.S. Daryan and M.A. Assareh, 2009. Probabilistic empirical green's function method in ground motion simulation. Am. J. Eng. Applied Sci., 2: 160-164. $\quad$ DOI: 10.3844/ajeassp.2009.160.164 
Liao, S.H., 2005. Expert system methodologies and applications-a decade review from 1995 to 2004. J. Expert Syst. Appl., 28: 93-103. DOI:10.1016/j.eswa.2004.08.003

McDonald, B. and M. Smithers, 1998. Implementing a waste management plan during the construction phase of a project: A case study. Constr. Manage. Econ., 16: 71-78. DOI: 10.1080/014461998372600

Muthusamy, N. and M. Ramalingam, 2003. Environmental impact assessment for urban planning and development using GIS. CSA Allumina.

Negnevitsky, M., 2005. Artificial intelligence: A guide to intelligent system. 2nd Edn., Addison-Wesley, England, ISBN: 0321204662, pp: 415.

Petts, J., 1995. Waste management strategy development: A case study of community involvement and consensus-building in Hampshire. J. Environ. Plan. Manage., 38: 519-536. DOI: 10.1080/09640569512797

Poon, C.S., 1997. Management and recycling of demolition waste in Hong Kong. Waste Manage. Res., $\quad 15$ : $561-572 . \quad$ DOI: $10.1177 / 0734242$ X9701500602
Poon, C.S., T.W. Yu and L.H. Ng, 2001. A Guide for Managing and Minimizing Building and Demolition Waste. Dept. of Civil and Structural Engineering, Hong Kong, ISBN: 9623673116, pp: 85.

Say, N.P., M. Yucela and M. Y1lmazerb, 2008. A computer-based system for environmental impact assessment (EIA) applications to energy power stations in Turkey: CEDINFO. J. Energy Pol.., 35: 6395-6401. DOI: 10.1016/j.enpol.2007.08.009

Shen, L.Y. and W.Y.V. Tam, 2002. Implementation of environmental management in the Hong Kong construction industry. Int. J. Proj. Manage., 20: 535-543. DOI: 10.1016/S0263-7863(01)00054-0

Shen, L.Y., V.W.Y. Tam, C.M. Tam and D. Drew, 2004. Mapping approach for examining waste management on construction sites. J. Constr. Eng. Manage., 130: 472-482. $\quad$ DOI: 10.1061/(ASCE)0733-9364(2004)130:4(472)

Solaimani, K., S. Modallaldoust and S. Lotfi, 2009. Soil erosion prediction based on land use changes (a case in neka watershed). Am. J. Agric. Biological Sci., 4: 97-104. DOI: 10.3844/ajabssp.2009.97.104

Spivey, D.A., 1974. Construction solid waste. J. Constr. Div., 100: 501-506. 